\title{
STRUKTUR KONSTRUKSI ARSITEKTUR TRADISIONAL BANGUNAN TRADISIONAL KEDA SUKU ENDE LIO DI PERMUKIMAN ADAT WOLOTOLO
}

\author{
Mukhlis A. Mukhtar ${ }^{1}$ Galih Widjil Pangarsa ${ }^{2}$ dan Lisa Dwi Wulandari ${ }^{3}$ \\ 1 Arsitektur Lingkungan Binaan, Universitas Brawijaya \\ 2 Arsitektur, Universitas Brawijaya \\ 3 Arsitektur, Universitas Brawijaya \\ mukhtardesign@yahoo.com
}

\begin{abstract}
Abstrak
Arsitektur Tradisional Ende Lio mempunyai kekhasan dan ciri tersendiri baik dalam bentuk arsitekturalnya maupun filosofi yang dikandung bentuk bangunannya dan mempunyai hubungan yang erat dengan setting sosial budaya masyarakat. Tujuan pembahasan dalam jurnal ini mengenal bagain-bagian struktur konstruksi bangunan tradisional sao keda yang merupakan bangunan tradisional simbol permukiman adat Suku Ende Lio. Metode yang digunakan adalah metode diskriptif analisis, yaitu dengan cara memaparkan berbagai data yang berkaitan dengan arsitektur tradisional Ende Lio, serta kemudian menganalisisnya berdasarkan bagian-bagian struktur konstruksi bangunan sao keda sebagaimana satu kesatuan bangunan Sehingga dapat dihasilkan suatu kesimpulan akhir tentang karakteristik arsitektur tradisional sao keda Suku Ende Lio. Hasil analisis simpulkan bahwa arsitektur tradisional sao keda Suku Ende Lio mempunyai keragaman struktur konstruksinya, mulai dari struktur leke lewu (pondasi), struktur maga (lantai), struktur wisu (kolom), struktur leke raja, mangu (tiang noc) dan struktur jara (kudakuda) semuanya merupakan bagain-bagian dari struktur konstruksinya pada bangunan sao keda arsitektur Ende Lio yang mempunyai karakteristik bentuk dan fungsinya masing-masing.
\end{abstract}

Kata Kunci : Arsitektur Tradisional, struktur konstruksi, Sao Keda, Ende Lio

\begin{abstract}
Traditional architecture of Ende Lio has its own characteristics in the form of the philosophy conceived by the shape of the building and closely relates with the sociocultural setting of the community. The purpose of this research was to investigate the parts of the structure of the traditional building construction the Sao Keda, a traditional building symbol of indigenous tribes settlements Ende-Lio. The method used was descriptive analysis by way of exposing a wide range of data relating to traditional architecture Ende Lio and then analysing it based on the parts of the structure of the Sao as a single entity. The results concluded that the Sao Keda's traditional architecture of The Ende Lio people had a diversity in the structure of its construction, starting from the structure of leke lewu (Foundation), the structure of the maga (floor), the structure of wisu (column), the structure of leke raja, mangu (noc pole) and the structure of jara (easel), which were all the parts of the structure of the building construction The Sao Keda of Ende Lio which had its own characteristic, form and function respectively.
\end{abstract}

Keywords: traditional architecture, construction structure, Sao Keda, Ende Lio 


\section{Pendahuluan}

Beraneka ragam arsitektur tradisional di Indonesia menandakan Indonesia memiliki seni budaya yang luas dan berbeda satu sama lainnya. Salah satunya rumah tradisional Suku Ende Lio yang hadir dengan gaya yang berbeda sesuai dengan kultur budaya dan alamnya. Suku Ende Lio berada di Kabupaten Ende Propinsi Nusa Tenggara Timur. Penduduk asli orang Ende biasa disebut orang Lio. Suku Ende Lio merupakan suku tertua yang ada di pulau Flores, selain Suku Ende Lio ada juga Suku Ende yang garis keturunannya berasal dari Bugis. Mata Pencaharian masyarakat Lio-Ende sebagian besar adalah bertani dan nelayan.

Permukiman Adat Desa Wolotolo merupakan bagian dari permukiman Suku Ende Lio yang berada di Kabupaten Ende. Jarak permukiman Adat Desa Wolotolo dari pusat Kota Ende Sekitar 20km. Seperti permukiman Suku Ende Lio pada umumnya, Desa Wolotolo sendiri merupakan desa yang masih menjaga adat istiadat budaya Suku Ende Lio. Hal ini bisa dilihat dari pola permukimannya yang masih memegang nilai-nilai budaya dan tradisi setempat. Permukiman adat Suku Ende Lio di Desa Wolotolo dipimpin oleh empat Mosa Laki (Kepala Suku) dan tujuh Kopo Kasa (Wakil Kepala Suku). Kepala Suku dan Kopo Kasa memegang peranannya masing-masing sesuai dengan tugas yang diamanatkan turun temurun dari nenek moyang sebelumnya. Keempat Kepala Suku bertempat tinggal di sao ria (Rumah Besar) masing-masing..

Suku Ende Lio di Desa Wolotolo memiliki berbagai macam elemen permukiman adat bangunan mulai dari sao ria (Rumah Besar), sao keda (tempat musyawarah), kanga (arena lingkaran), tubu musu (tugu batu), rate (kuburan) dan kebo ria (lumbung). Bangunan-bangunan adat yang ada memiliki berbagai macam bentuk struktur dan konstruksinya sesui dengan fungsi bangunan itu masing -masing.

\section{Metode Pembahasan}

Metode yang digunakan untuk pengumpulan data dalam kajian ini adalah melalui survey atau penelusuran literatur yang terkait dengan arsitektur Ende Lio yang ada di pulau Flores. Metode yang digunakan pada tahapan analisis data adalah metode diskriptif analisis, yaitu dengan cara memaparkan berbagai data yang berkaitan dengan struktur konstruksi arsitektur tradisional sao keda Suku Ende Lio, serta kemudian menganalisisnya berdasarkan bagian-bagian dari struktur konstruksi bangunan sao keda. Sehingga dapat dihasilkan suatu kesimpulan akhir tentang karakteristik arsitektur tradisional sao keda Suku Ende Lio.

Daerah - daerah kecamatan yang termasuk wilayah suku Ende Lio adalah Daerah kecamatan Wolowaru, kecamatan Maurole dan kecamatan Detusoko. Batasbatas kecamatan yang termasuk wilayah suku ende lio (Lihat Gambar 2). Desa Wolotolo berada di kecamatan Detusoko Kabupaten Ende merupakan salah satu Desa di Propinsi Nusa Tenggara Timur dengan luas wilayah Kecamatan 204,65 $\mathrm{Km}^{2}$. Posisi Kabupaten Daerah Tingkat II Ende dari letak geografisnya antara lain dalam koordinat $8^{\circ} 26^{\prime} 24,71^{\prime \prime}$

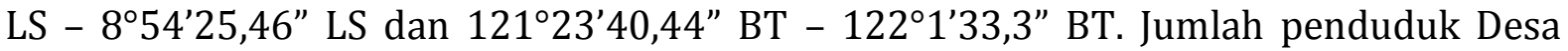
Wolotolo kurang lebih 535 jiwa.

Suku Ende Lio dikenal sangat memegang teguh keyakinan dan kepercayaan mereka terhadap wujud tertinggi yang disebut Du'a $^{\prime} \operatorname{sga}^{\prime}$ e, Nitupa'i atamata atau babo mamo. Dalam konteks ini, Du'a Ngga'e berada pada titik puncak yang wajib disujud. Sementara Nitupa'i atamata wajib dihormati. Masyarakat Suku Ende Lio percaya adanya 
kekuatan adikodrati serta percaya bahwa roh-roh para leluhur dan roh-roh alam sangat berpengaruh dalam kehidupan mereka.

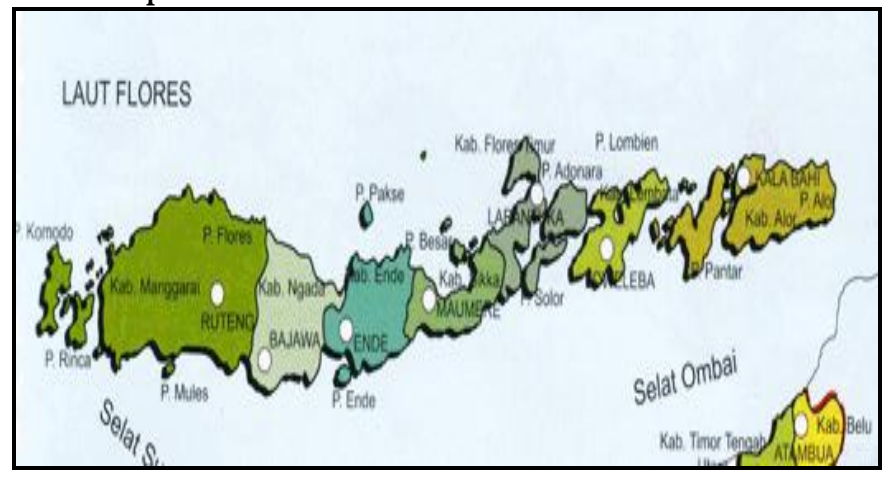

Gambar 1. Peta Pulau Flores yang ada di Propinsi NTT Sumber : Kab. Ende Dalam Angka 2005

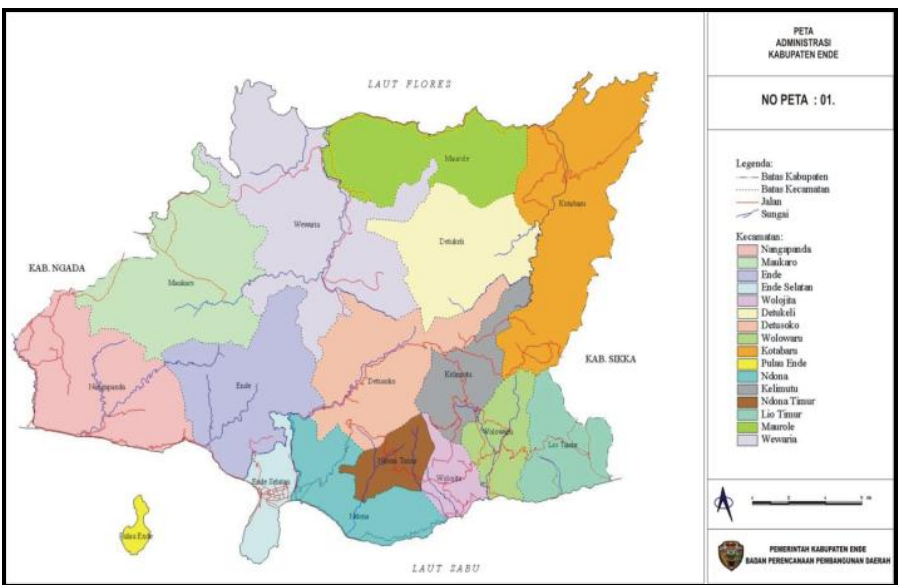

Gambar 2. Peta Kabupaten Ende Sumber : Kab. Ende Dalam Angka 2005

\section{Hasil Pembahasan}

\subsubsection{Bangunan Tradisional Sao Keda Suku Ende Lio Desa Wolotolo}

Sao keda adalah bangunan tradisional dengan atap ilalang yang menjulang tinggi; merupakan balai rakyat, tempat dilaksanakan musyawarah adat beserta upacaraupacara adat yang dipimpin oleh para Mosalaki Anakalo Fai Walu (masyarakat adat). Digunakan sebagai tempat berkumpul para tua adat, dapat juga tempat penyimpanan benda-benda peninggalan para leluhur (ana deo, kiko tana watu dan gading tua). Sao Keda dianggap sebagai simbol kesakralan masyarakat Suku Ende Lio karena merupakan cikal bakal permukiman adat.

Letak bangunan Sao Keda biasanya berdekatan dengan kanga dimana berada tepat didepannya. Posisi Sao keda dan kanga merupakan daerah yang paling tertinggi di antara permukiman lain karena dianggap sakral oleh masyarakat Suku Ende Lio pada umumnya. Membangun sao keda sama aja membangun rumah adat lainnya hanya keda tidak mempunyai dinding, letaknya menghadap ke gunung adapula menghadap ke laut dan ada pula menghadap ke dua arah tersebut karna arwah para leluhur datangnya dari arah tersebut. 


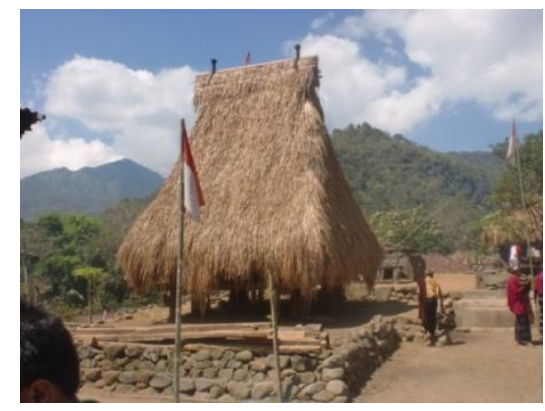

Gambar 3. Sao Keda Suku Ende Lio Di Desa Wolotolo Sumber : Dokumentasi Pribadi, 2011

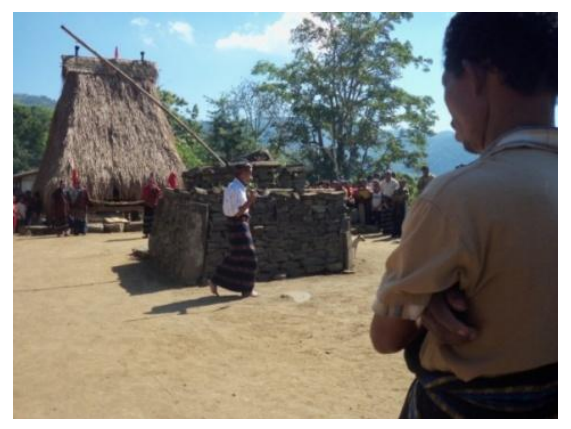

Gambar 4. Ruang Luar Bagian Depan Sao Keda Suku Ende Lio Di Desa Wolotolo Sumber : Dokumentasi Pribadi, 2011

\subsubsection{Bangunan Tradisional Sao Keda merupakan Simbol Pemukiman Adat}

Struktur spasial permukiman tradisional dikategorikan dalam dua hubungan mendasar, yaitu pertama antara global space dengan element space dan yang kedua adalah hubungan antara elemen space itu sendiri. Elemen - elemen tertentu suatu bangunan akan sangat menentukan dalam mengindetikasi dan mengklasifikasi the spirit of space dari suatu tempat. Hal inilah dapat diketahui pergerakan - pergerakan tertentu yang bersifat ritual, sehingga dapat mengetahui daerah tempat sakral atau dapat menentukan nilai kesakralan suatu tempat di permukiman tradisional seperti pada pemukiman tradisional desa Wolotolo.

Permukiman Adat desa Wolotolo merupakan permukiman yang mengandung the spirit of space banyak kesakaralan dan makna, mulai dari elemen - elemen permukiman yang membentuk suatu kawasan. Pada mulanya terbentuk terbentuk suatu pemukiman Suku Ende Lio adalah bangunan sao keda dan kanga dimana sao keda merupakan bangunan pertama yang cikal bakal terbentuk suatu pola permukiman tradisional Suku Ende Lio sedangkan kanga sebagai daerah ritual dalam menjalani seremonial adat.

Sao keda merupakan bangunan pertama yang ada dalam perkampungan adat, dimana pada saat itu masyarakat Suku Ende Lio membuka permukiman baru bangunan yang pertama adalah sao keda. Bangunan sao keda pada masa itu merupakan tempat peristirahatan masyarakat Suku Ende Lio sepulangnya dari berburu dan bertani. Di sekitar Sao Keda terdapat daerah pertanian yang kelamaan menjadi permukiman 
diakibatkan bertambahnya masyarakat yang datang mencari daerah pertanian dan buruan baru.

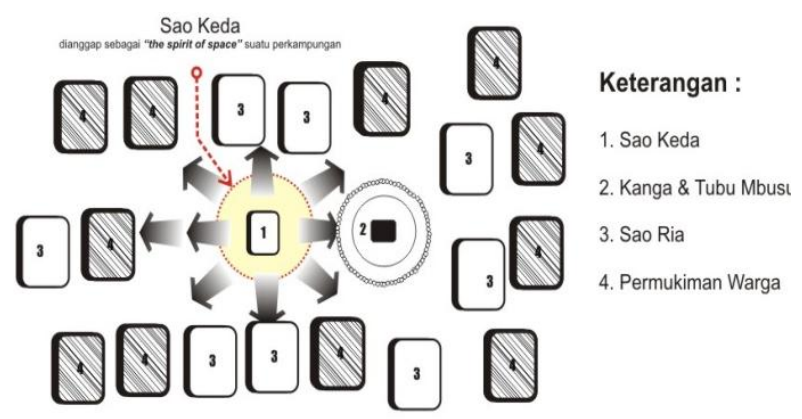

Gambar 5. Keda sebagai "The spirit of space" Permukiman adat Suku Ende Lio Sumber : Sketsa Analisa, 2012

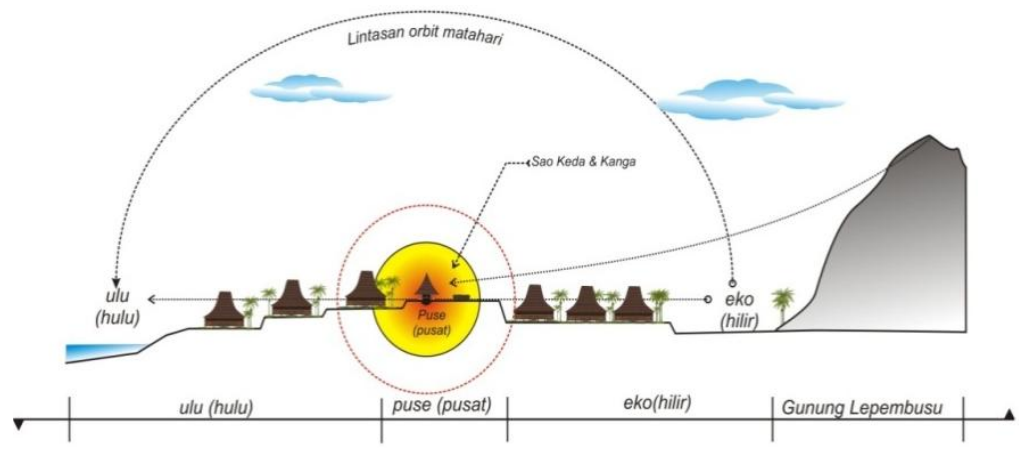

Gambar 6. Orientasi Pola Permukiman Suku Ende Lio Di Kampung Adat Wolotolo Sumber : Sketsa Analisa, 2012

Kaitan dengan kepercayaan yang diceritakan secara turun temurun oleh masyarakat Suku Ende Lio manusia pertama di wilayah Ende Lio turun dari gunung tertinggi yaitu gunung Lepembusu kemudian membangun rumah manusia pertama yaitu sao keda. Rumah manusia pertama ini menjadi semacam tempat ibadat dan pusat religius yang harus diwariskan secara turun temurun masyarakat adat Suku Ende Lio Setelah sao keda didirikan kemudian dibuat kanga untuk melakukan acara seremonial adat untuk melakukan persembahan terhadap Dua Ngae (tuhan dalam kepercayaan Suku Ende Lio).

\subsubsection{Struktur dan Konstruksi Bangunan Tradisional Sao Keda Desa Wolotolo}

Bagi masyarakat Suku Ende Lio Desa Wolotolo sao keda merupakan bangunan yang mempunyai keunikan struktur konstruksi tersendiri dengan bangunan lainnya. Ciri khas bangunan sao keda adalah bangunannya berbentuk persegi panjang yang mempunyai empat sudut utama masing - masing. Ukuran denah bangunan sao keda relatif kecil Cuma berukuran 6 x 4 meter yang memilki empat kolom sebagai struktur utama bangunan. Bangunan sao keda tidak memiliki dinding sebagai pembatas ruang. Ciri khas lain daripada di bagian depan dan belakang terdapat tenda teo (teras kecil) yang letaknya lebih rendah dari bagian dalam ruang sao keda berukuran $1 \mathrm{~m}$ x 4,6 m. Struktur bangunan sao keda adalah teknologi strukturnya sangat sederhana seperti rumah tradisonal pada umumnya yang ada di Indonesia. Hal itu ditunjukkan di 
beberapa sambungan kayunya yang tidak menggunakan paku maupun baut baja, melainkan kayu.

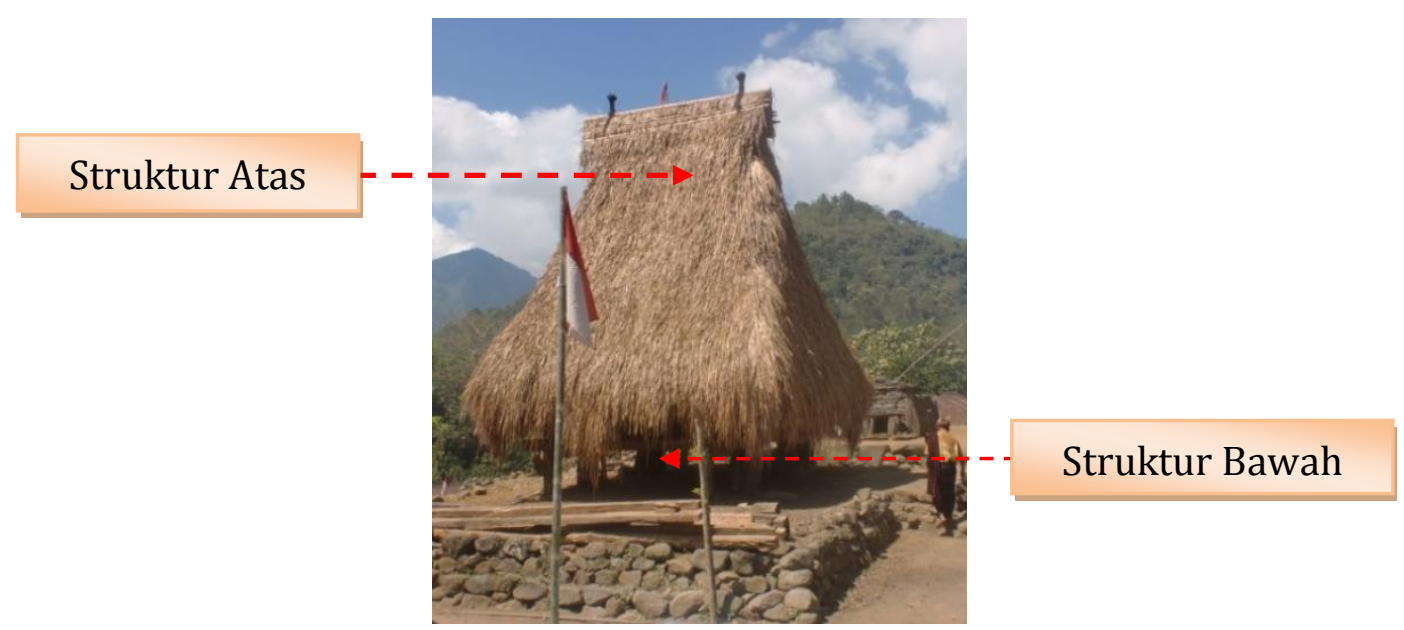

Gambar 7. Sao Keda Suku Ende Lio Di Desa Wolotolo

Sumber : Dokumentasi Pribadi, 2011

Struktur berkaitan erat dengan pemahaman anatomi bangunan, yang dikategorikan dalam dua kategori, yaitu: sub-structure (struktur bawah) dan upperstructure (struktur atas). Konstruksi berhubungan dengan metode, teknik atau cara, misalnya: mengikat, mengangkat, menyambung dan lain-lain. Berikut ini adalah struktur konstruksi bangunan tradisional sao keda Suku Ende Lio di Desa Wolotolo.

a. Struktur Bawah Sao Keda

1. Struktur Kuwu Lewa (Pondasi) Sao Keda

Sub struktur atau struktur bagian bawah bangunan adalah berupa landasan utama berdirinya sebuah bangunan yang dikenal istilah pondasi. Pondasi pada bangunan rumah sao keda menggunakan batu lonjong yang dipasang berdiri secara vertikal. Pondasi dalam bahasa Ende Lio disebut leke lewu yang berartikan tiang kolom pondasi. Bentuk dari pondasi rumah sao keda yang unik yaitu kolom bangunan hanya diletakkan diatas sebuah batu datar yang sudah terbentuk di alam. Tujuan pembuatan pondasi seperti ini adalah untuk menghindari keretakan atau pada kolom bangunan pada saat terjadi gempa, sedangkan bentuk lantai panggung bertujuan untuk memungkinkan sirkulasi udara dari bawah lantai dapat berjalan baik, sehingga kemungkinan terjadi kelembaban pada lantai bangunan sao keda dapat dihindari.

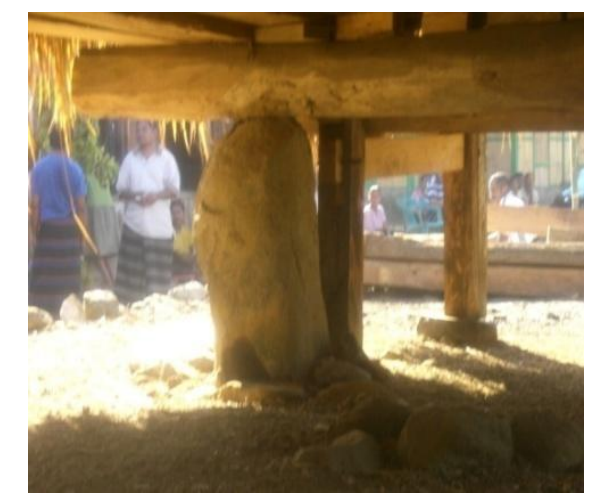

Gambar 8. Pondasi Bangunan rumah Sao Keda Suku Ende Lio Di Desa Wolotolo Sumber : Dokumentasi Pribadi, 2011 


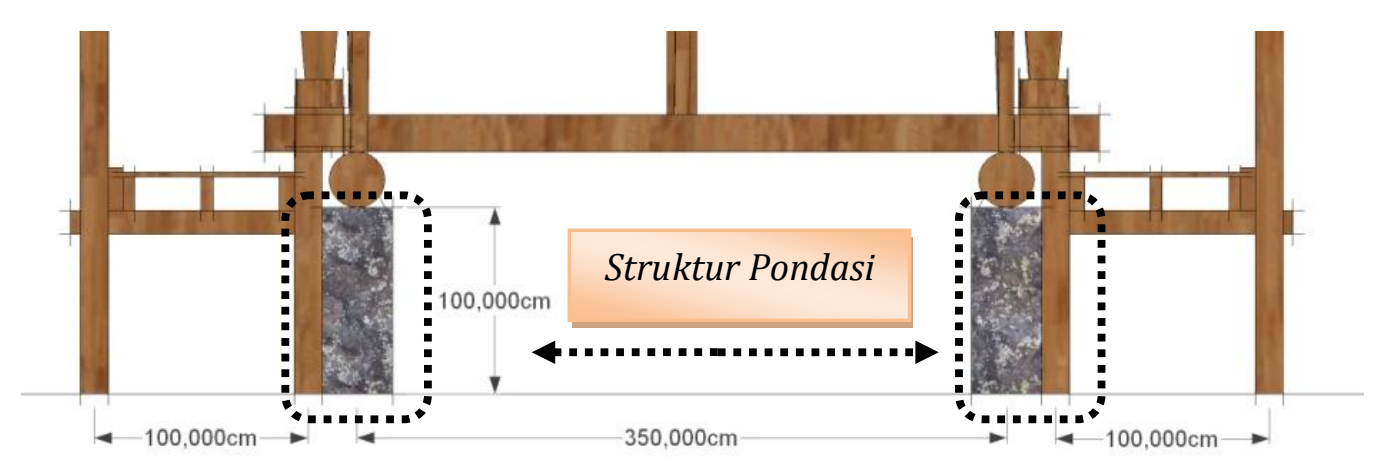

Gambar 9. Detail konstruksi Pondasi Rumah Sao Keda Suku Ende Lio Di Desa Wolotolo Sumber : Sketsa Analisa, 2012

\section{Struktur Maga (Lantai) Sao Keda}

Lantai rumah tradisional sao keda dalam bahasa Ende Lio biasa disebut maga yang terbuat dari bilah papan yang disusun sejajar satu arah. Struktur lantai pada sao keda terdiri dari dua bagian yaitu lantai tenda teo (teras gantung) dan lantai koja ndawa (lantai ruang dalam) yang membedakan keduanya adalah beda tinggi lantai tersebut. Alasan pembuatan lantai dari bilah papan adalah seperti yang telah dijelaskan di atas yaitu agar udara yang melewati kolong rumah dapat masuk ke ruang atas, selain itu dengan menggunakan lantai papan, tingkat kelembapan di dalam bangunan tradisional Keda juga akan berkurang, mengingat ketinggian lantai rumah tradisional Keda tidak seperti rumah tradisional lain pada umumnya yaitu berkisar antara $60-100$ centimeter dari permukaan tanah.

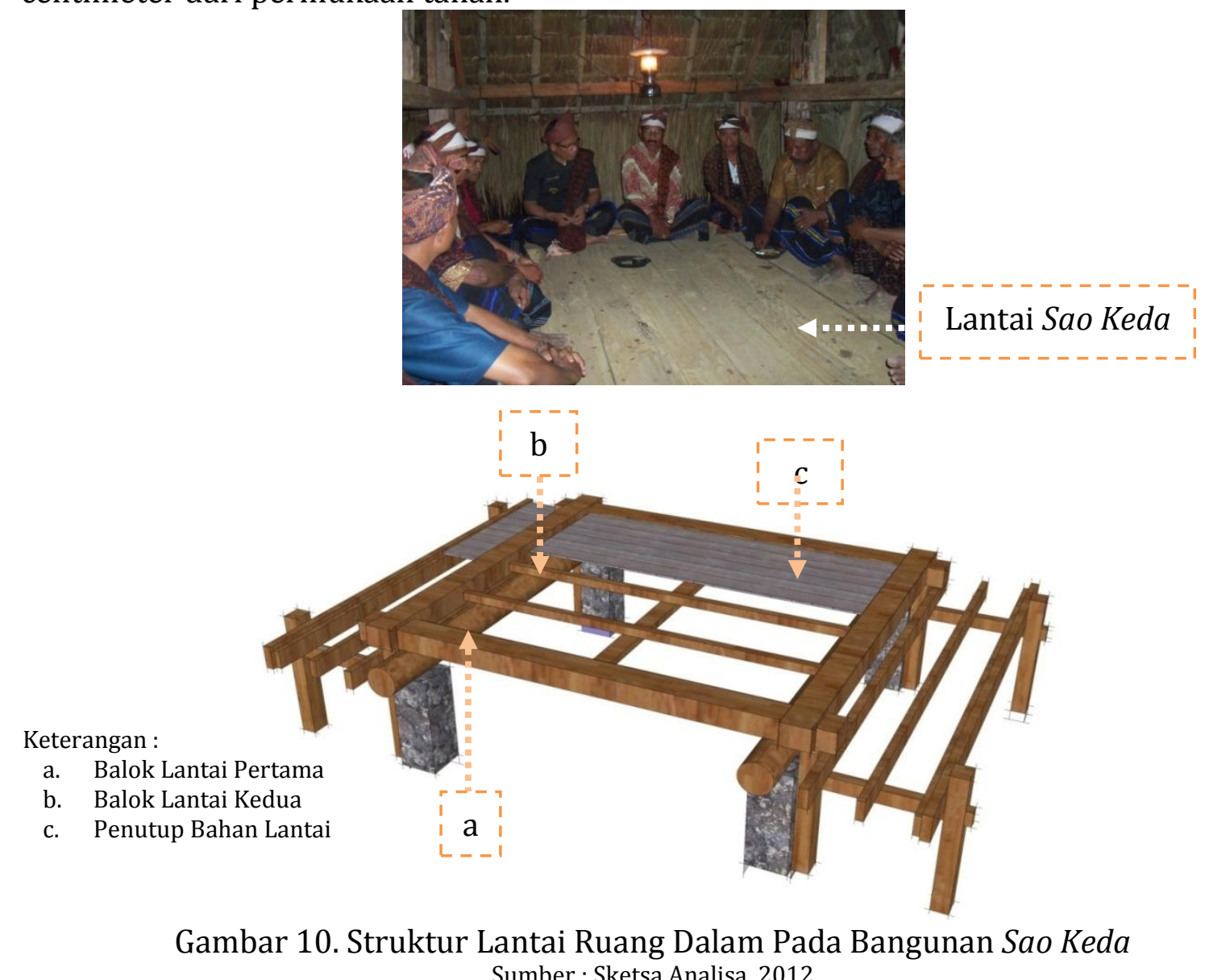

Sumber : Sketsa Analisa, 2012 


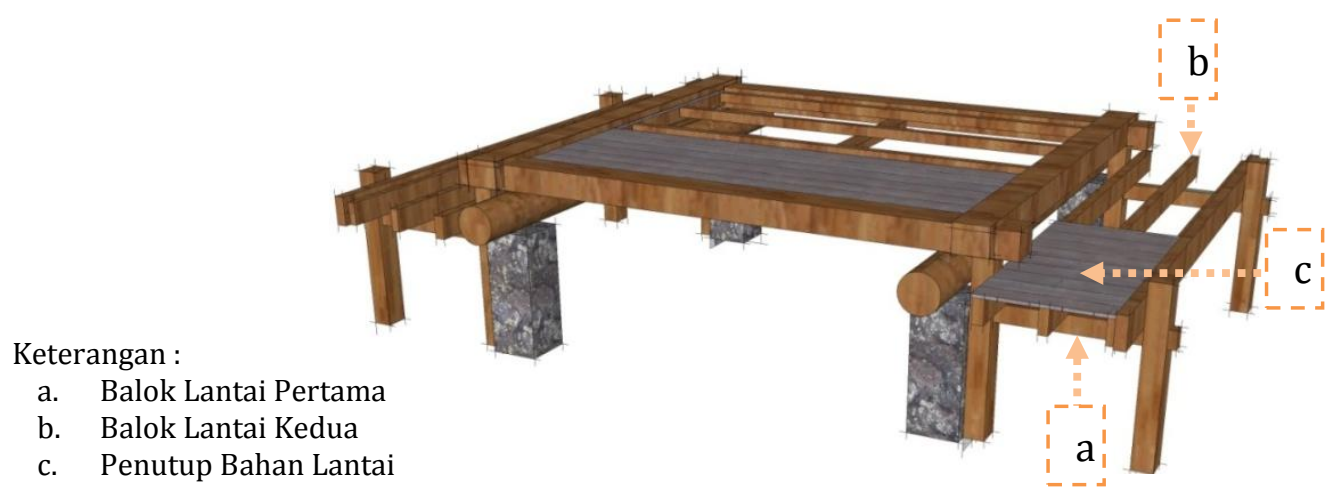

Gambar 11. Struktur Lantai Teras Kecil Pada Bangunan Sao Keda Sumber : Sketsa Analisa, 2012

Keterangan :

a. Lantai (maga) ruang dalam

b. Lantai (maga) ruang luar

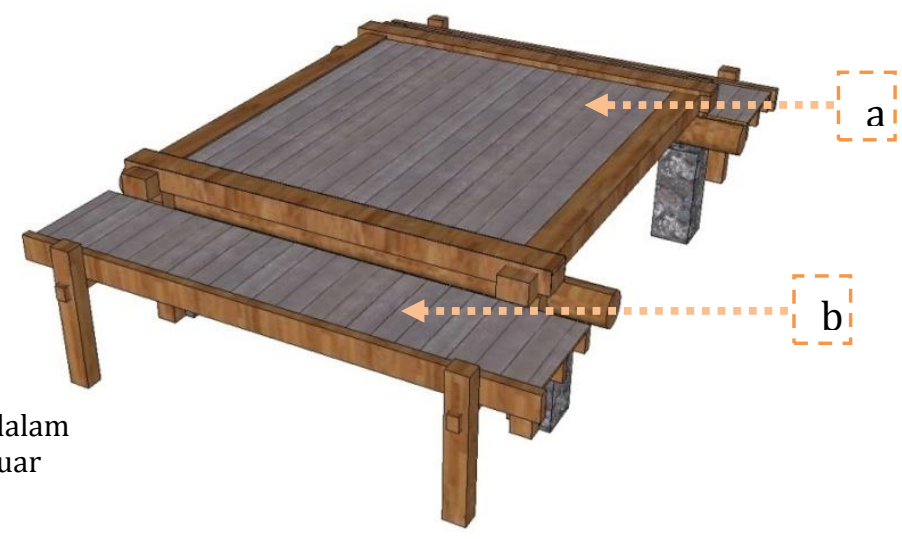

Gambar 12. Struktur Lantai Pada Bangunan Sao Keda Suku Ende Lio Di Desa Wolotolo Sumber : Sketsa Analisa, 2012

\section{b. Struktur Atas Sao Keda}

1. Strukur Atas Lantai adalah Wisu (tiang kolom tak berdiding) Sao Keda

Pada bangunan tradisional sao keda struktur atas lantai mempunyai empat buah wisu (tiang kolom) penyangga yang ditopang dari isi ine wawo (balok kayu palang bagian atas) yang memiliki panjang $\pm 400 \mathrm{~cm}$ yang ditopang juga isi mbasi (balok kayu palang bagian bawah) yang panjang $\pm 450 \mathrm{~cm}$. Bangunan Sao Keda tidak mempunyai dinding pembatas ruang. Tinggi masing - masing tiang kolom bangunan Sao Keda \pm 120 cm dimana bentuk dari kolom berbeda dengan kolom bangunan lainnya. Tiang kolom berbentuk bulat di bagian bawah dan bagian atasnya berbentuk menyerupai sebuah kerucut segi empat. Pada masing - masing kolom mempunyai ciri khas ukiran yang mempunyai filasofi bagi masyarakat Suku Ende Lio khususnya Desa Wolotolo.

Diantara tiang kolom samping kanan dan samping kiri sao keda terdapat leke raja yaitu satu tiang badan rumah yang panjangnya $\pm 120 \mathrm{~cm}$, letaknya di bagian tengah yang menghubungkan dengan tiang mangu yang panjangnya $\pm 450 \mathrm{~cm}$ untuk menahan bubungan yang membentuk atap rumah atau ubu sao yang diikat oleh isi mbasi wawo (balok kayu palang bagian atas) yang memliki panjang $\pm 650 \mathrm{~cm}$. Untuk rumah sao keda tiang leke raja dan tiang mangu menjadi satu tiang dan kayu palang menghubungkan tiang mangu yaitu saka ubu, kedua tiang leke raja ini dipasang dengan menggunakan seremonial adat Suku Ende Lio. Pada tiang leke raja dan mangu mempunyai seni ukiran simbol binatang reptil dan binatang lainya bisa dilihat pada gambar. 


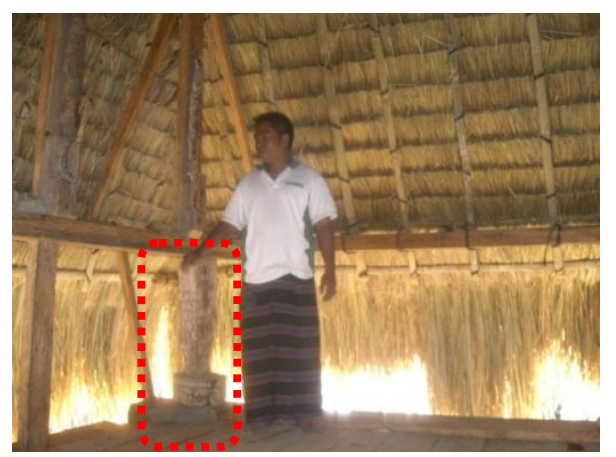

Gambar 13. Struktur Tiang Kolom Rumah Sao Keda Suku Ende Lio Di Desa Wolotolo Sumber : Dokumentasi Pribadi, 2011

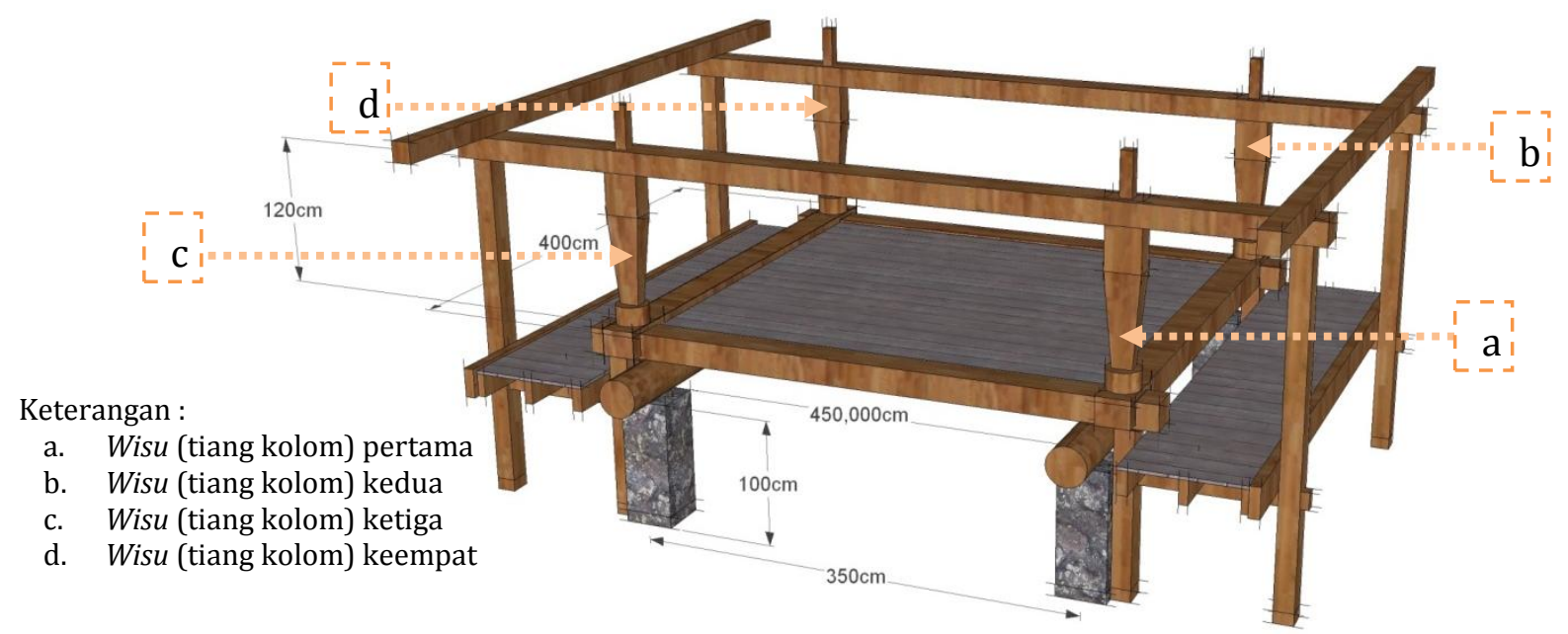

Gambar 14. Detail Struktur Tiang Kolom Sao Keda Suku Ende Lio Di Desa Wolotolo Sumber : Sketsa Analisa, 2012

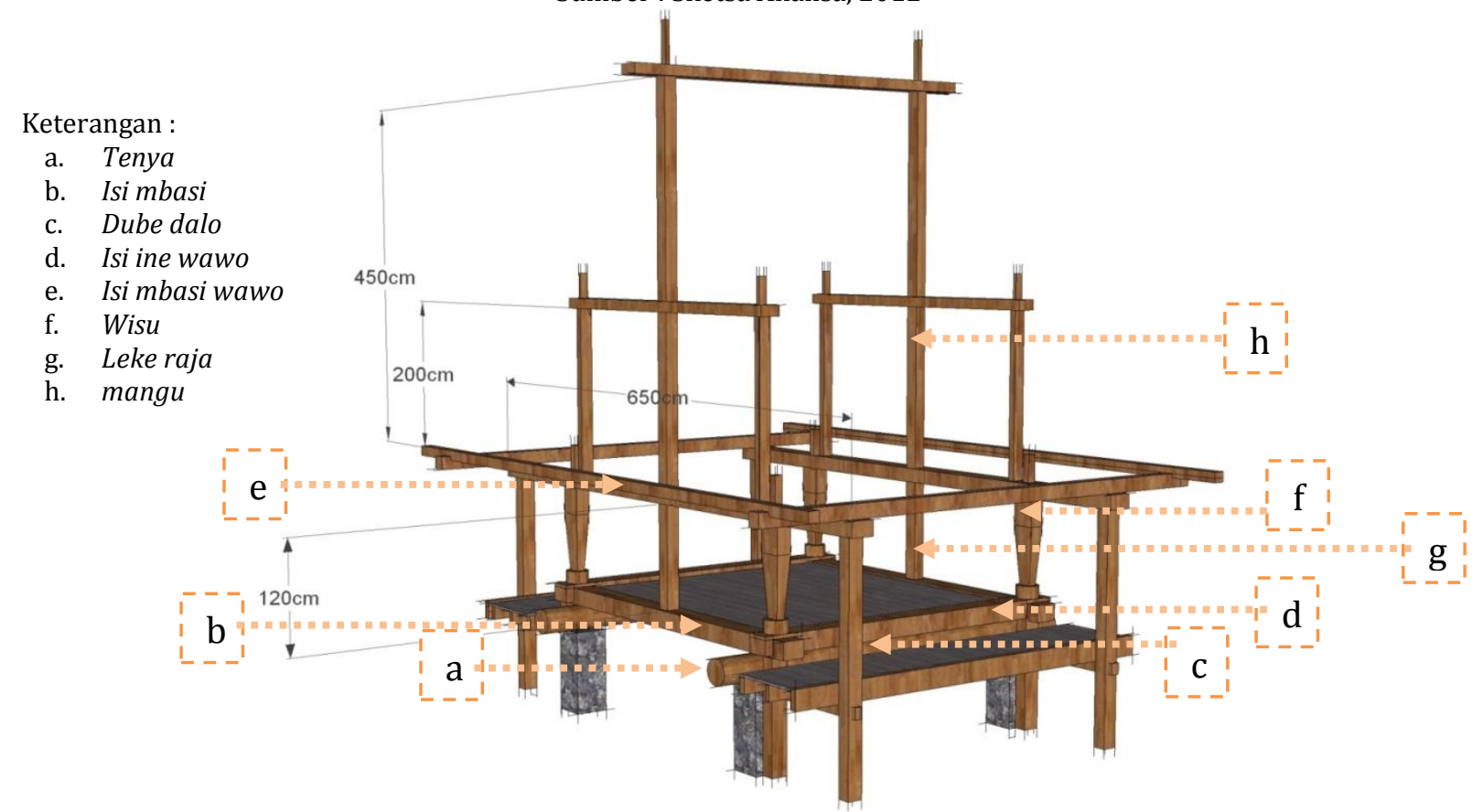

Gambar 15. Struktur Konstruksi Atas Lantai Bangunan Sao Keda Di Desa Wolotolo Sumber : Sketsa Analisa, 2012 


\section{Struktur Atap Sao Keda}

Struktur rangka atap merupakan struktur bagian atas bangunan sao keda. Tiang mangu (tiang nok) pada bagian struktur rangka atap sao keda berfungsi sebagai pembentuk struktur kuda - kuda yang dihubungkan dengan saka ubu (bubungan). Struktur kuda - kuda pada bagian rangka atap sao keda disebut jara yang merupakan kayu palang yang menghungkan antara ujung tiang mangu atau leke raja untuk membentuk bubungan atap sao keda. Pada bagian struktur atap sao ria terdapat juga pella yang merupakan kayu palang yang membentuk sudut bubungan yang menghubungkan tiang mangu atau leke raja dengan tiang wisu (kolom).

Pada bagian struktur rangka atap terdapat lare serta juga eba (gording) yang terbuat dari bilah bambu yang panjang dan letaknya sejajar dengan gola yang merupakan kayu palang membentuk segi empat persegi sebagai penyanggah kuda kuda dan pella, jaraknya berdekatan atau disesuaikan dengan Ngu Ki (alang-alang penutup atap). Struktur yang terakhir adalah ate ubu (atap) yang bahannya adalah nao (ijuk) sebagai pengikat dan $k i$ (alang-alang) yang dipasang secara berselang seling dari bawah ke atas.

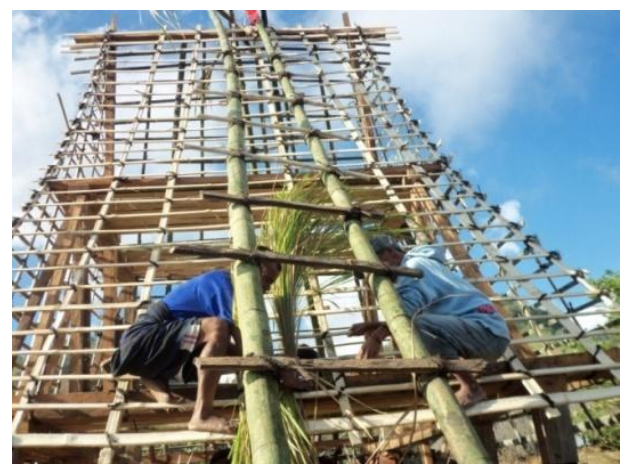

Gambar 16. Struktur Konstruksi Rangka Atap Sao Keda Suku Ende Lio Di Desa Wolotolo Sumber : Dokumentasi Pribadi, 2011

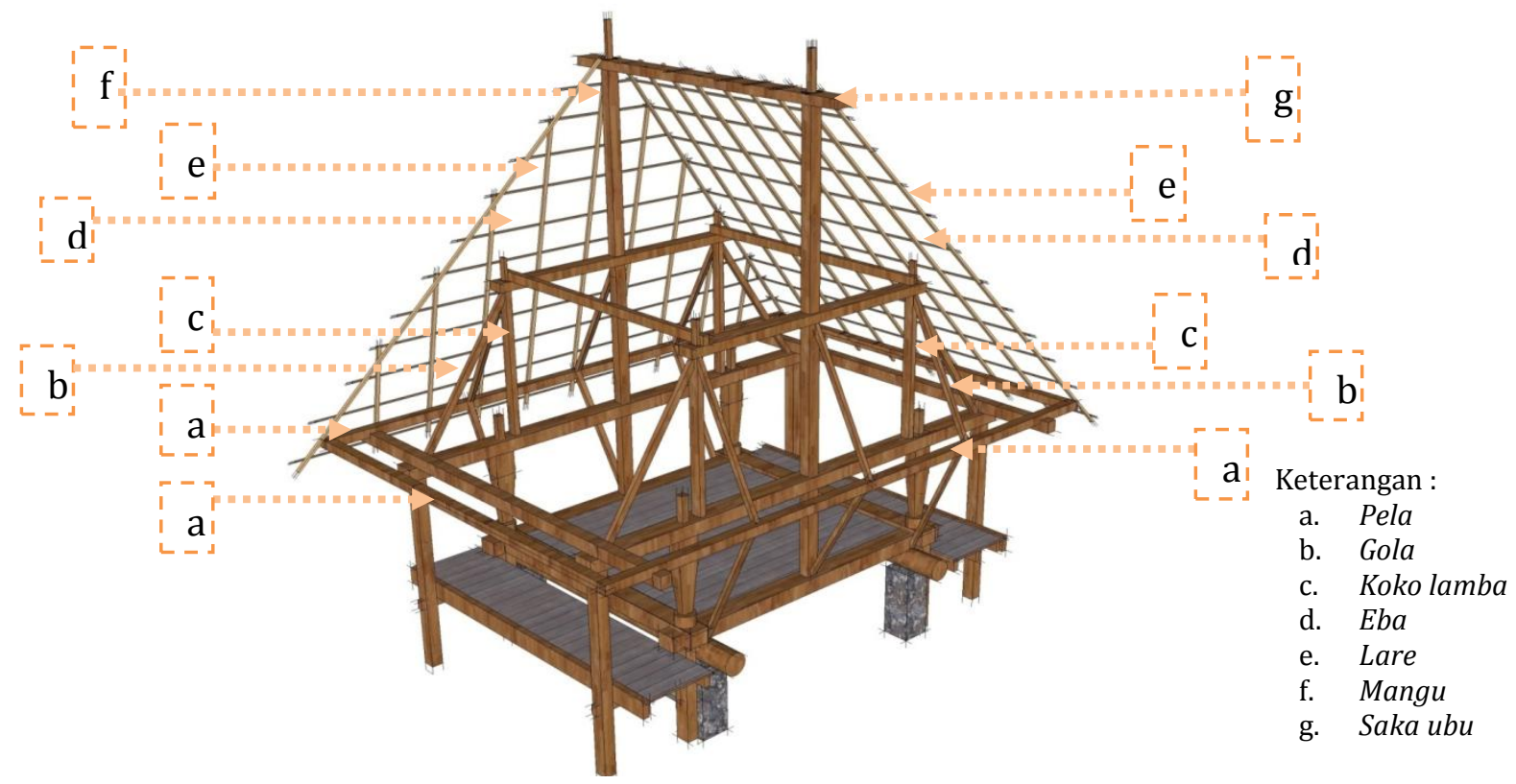

Gambar 17. Struktur Konstruksi Rangka Atap Bangunan Sao Keda di Desa Wolotolo Sumber : Sketsa Analisa, 2012 


\subsubsection{Filosofi Bentuk Bangunan Sao Keda}

Bentuk rumah adat sao keda persegi empat dengan atap yang menjulang tinggi sebagai simbol kesatuan dengan sang pencipta. Bentuk atap diyakini memiliki bentuk seperti layar perahu sebagaimana diceritakan nenek moyang pertama Suku Ende Lio datang menggunakan perahu. Di puncak bagian atas terdapat dua ornamen yang memiliki simbol yaitu kolo sao keda (kepala rumah keda) dan kolo sao ria (kepala rumah besar) dimana diyakini kedua bangunan memiliki hubungan spiritual.

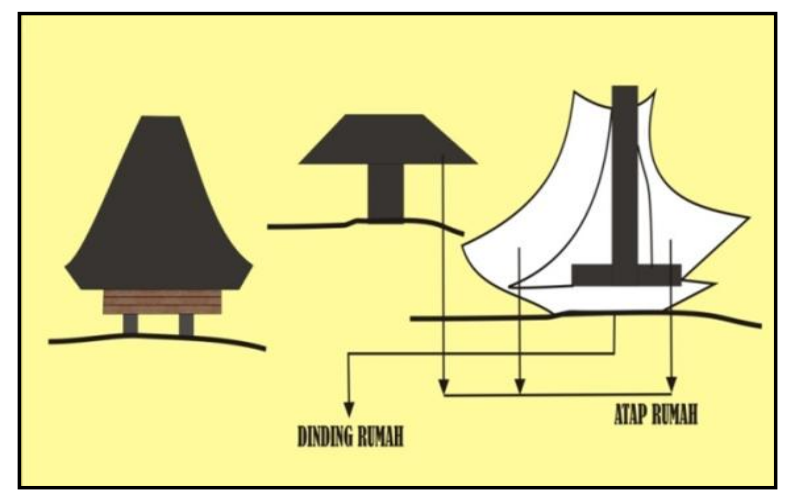

Gambar 18. Bentuk Atap Rumah Sao Keda yang Berbentuk Layar Perahu Sumber : Sketsa Analisa, 2012

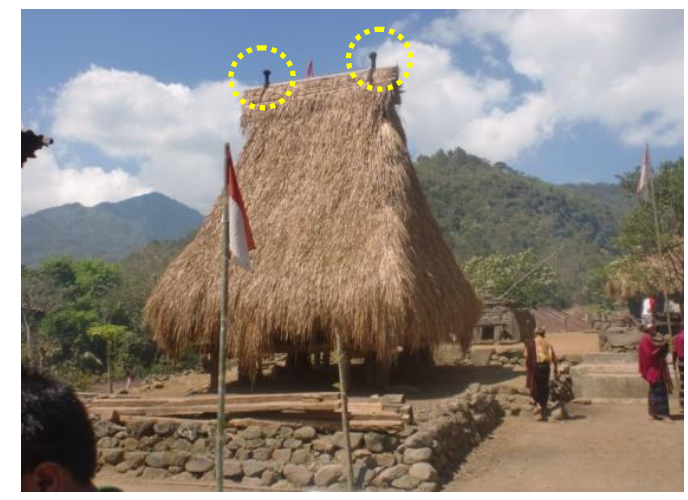

Gambar 18. Kolo Sao Keda dan Kolo Sao Ria Suku Ende Lio Di Desa Wolotolo Sumber : Dokumentasi Pribadi, 2011

\section{Kesimpulan}

Arsitektur tradisional sao keda Suku Ende Lio benar-benar merupakan ungkapan dan cerminan sosial budaya masyarakatnya, sebagaimana dijelaskan didalam bagianbagain strukur konstruksi yang ada di permukiman adat desa Wolotolo. Sehingga setiap hasil karya yang diciptakan tersebut benar-benar mempunyai landasan yang kuat dan khas, baik strukturnya, bentuk, tata ruang, dan juga pemakaian ornamenornamennya. Bentuk yang khas dan spesifik tersebut mampu menampilkan bentuk yang selaras dengan lingkungannya, walapun ada kontradiksi bentuk yang ditemukan tetapi ada keserasian antara alam dan lingkungan binaan yang diciptakan. Sehingga bentuk yang mempunyai dasar yang kuat dan ciri khas tersebut mudah diingat dan dikenal orang pengamat sebagaimana elemen-elemen yang ditampilkannya secara kompak dan menyatu. Hasil analisis disimpulkan bahwa aristektur tradisional sao keda Suku Ende 
Lio mempunyai keragaman struktur konstruksinya. Mulai dari struktur leke lewu (pondasi), struktur maga (lantai), struktur wisu (kolom), struktur leke raja, mangu (tiang noc) dan struktur jara (kuda-kuda) semuanya merupakan bagain-bagian dari struktur konstruksinya pada bangunan sao keda arsitektur Ende Lio yang mempunyai karakteristik bentuk dan fungsinya masing - masing.

\section{Daftar Pustaka}

Aron Mbete, dkk (2006). Khazanah Budaya Lio Ende. Pustaka Larasan. Dinas Pendidikan dan Kebudayaan Kabupaten Ende.

Aset Seni Budaya Daerah Kabupaten Ende. (2003). Dinas Pariwisata Kab. Ende.

Ende dalam Angka. (2005). Penerbit Nusa Indah. Ende.

Moleong, Lexy. (1990). Metodelogi Penelitian Kualitatif. Bandung: PT Remaja Rosda Karya.

Muhadjir, Noeng. (1996). Metode Penelitian Kualitatif. Yogyakarta: Rake Sarasin.

Soemargono, K. et.al. (1992). Profil Propinsi RI, Nusa Tenggara Timur. Jakarta: PT lntermasa.

Soewondo, Bambang, et.al. (1987). Adat Istiadat Daerah Nusa Tenggara Timur. Jakarta: Depdikbud. 